\title{
RBM10 wt Allele
}

National Cancer Institute

\section{Source}

National Cancer Institute. RBM10 wt Allele. NCI Thesaurus. Code C115383.

Human RBM10 wild-type allele is located in the vicinity of Xp11.23 and is approximately $42 \mathrm{~kb}$ in length. This allele, which encodes RNA-binding protein 10, plays a role in the binding to and processing of RNA. Mutation of the gene is associated with TARP syndrome. 